\title{
ERRATUM
}

Anne Volbeda $\cdot$ Lydie Martin · Christine Cavazza

Michaël Matho · Bart W. Faber - Winfried Roseboom

Simon P. J. Albracht · Elsa Garcin · Marc Rousset

Juan C. Fontecilla-Camps

\section{Structural differences between the ready and unready oxidized states of [NiFe] hydrogenases}

Published online: 10 June 2005

(C) SBIC 2005

\section{J Biol Inorg Chem (2005) 10:239-249}

Wrong deposition codes were inserted in the last sentence of the Acknowledgements.

The correct codes are 1YQ9 instead of IYQY for crystal A1, 1YQW instead of IYQN for crystal A2 and 1YRQ instead of IYRQ for the Ni-B state.

The online version of the original article can be found at http:// dx.doi.org/10.1007/s00775-005-0632-x

A. Volbeda $(\bowtie) \cdot$ L. Martin $\cdot$ C. Cavazza $\cdot$ M. Matho

E. Garcin · J. C. Fontecilla-Camps (ه)

Laboratoire de Cristallographie et de Cristallogenèse des Protèines, Institut de Biologie Structurale J.P. Ebel (CEA-CNRS-UJF),

41 rue Jules Horowitz, 38027 Grenoble Cédex 1, France

E-mail: anne.volbeda@ibs.fr

Tel.: + 33-4-38789606

Fax: + 33-4-38785122

E-mail: juan.fontecilla@ibs.fr

Tel.: + 33-4-38785920

Fax: + 33-4-38785122

B. W. Faber · W. Roseboom · S. P. J. Albracht Biochemistry, Swammerdam Institute for Life Sciences, University of Amsterdam, Plantage Muidergracht 12, 1018 TV Amsterdam, The Netherlands

M. Rousset

Unité de Bioénergétique et Ingénierie des Protéines, Institut de Biologie Structurale et Microbiologie, CNRS, 31 chemin Joseph Aiguier, Marseille Cédex 20, France 